\title{
Zarys mechanizmów językowych w niemieckich kawalach
}

\section{Dorota Biadala}

Uniwersytet Heidelberg, Niemcy

dorota.biadala@slav.uni-heidelberg.de

\section{Streszczenie}

Obiektem bliższej obserwacji w niniejszym artykule jest językowa analiza niemieckich kawałów (dowcipów) jako krótkich form humorystycznych, w szczególności analiza zawartych $w$ nich „, nieporozumień” językowych, które sa strategicznym wyróżnikiem gatunkowym tych tekstów. Ich głównym zadaniem jest zażartowanie z kogoś i rozśmieszenie innych. Przeprowadzona analiza lingwistyczna „,nieporozumien’” językowych porusza różne aspekty komunikacyjne osadzone $w$ perspektywie społecznej: zarówno pragmatykę komunikacji międzykulturowej, kreatywność $w$ komunikacji wewnatrzkulturowej, jak $i$ humor $w$ kulturze $i$ komunikacji. Materiat badawczy wykorzystany do niniejszej analizy tworzy korpus utworzony z ponad 400 niemieckich kawałów pochodzacych z różnych źródel, w większości zaczerpniętych ze zbiorów internetowych. Celem niniejszego opracowania jest zaprezentowanie różnych perspektyw badawczych $i$ analiza językowych mechanizmów służacych tworzeniu „nieporozumien" językowych na podstawie wprowadzonych 13-tu kategorii opisujacych bliżej gatunek tekstu 'kawat' z uwzględnieniem niemieckiej specyfiki kulturowej.

Stowa kluczowe: żart, humor, językoznawstwo kontrastywne polsko-niemieckie

Abstract

Outline of Linguistic Mechanisms in German Jokes

The main subject of this article is the linguistic analysis of German jokes as the short humorous formats, emphasis is placed on the analysis of various language-related "misunderstandings" found in these jokes, whose are strategic genre differentiator of these texts. Their main function is to make fun of someone and to make others laugh. The analysis of these language-related "misunderstandings" raises various communicative issues that are rooted in the social perspective, such as: pragmatics of intercultural communication, creativity in intracultural communication, or humour in culture and in communication. The research material used for this analysis is composed of over four hundred German jokes coming from various sources, with the largest number of texts from internet sources. The aim of this publication is to present various research perspectives and to analyse linguistic mechanisms used in the creation of language-related "misunderstandings" on the basis of thirteen categories that describe the genre 'joke' considering the German cultural specificity. 
Keywords: joke, humour, Polish-German contrastive linguistics

\section{Wstęp}

Celem artykułu jest krótkie omówienie istoty kawału w badaniach nad humorem oraz podjęcie próby ustalenia mechanizmów językowych występujących w niemieckich kawałach, jak również zaprezentowanie różnych perspektyw badawczych i przeprowadzenie krótkiej kognitywno-lingwistycznej analizy niemieckich kawałów. Głównym obiektem moich badań naukowych i bliższej obserwacji w niniejszym artykule są niemieckie kawały (żarty, dowcipy) i zawarte w nich rzekome „,nieporozumienia” językowe, które są strategicznym wyróżnikiem gatunkowym tych tekstów. Głównym zadaniem tych zamierzonych nieporozumień językowych jest zażartowanie z kogoś / czegoś i rozśmieszenie innych. Kawał oparty jest na wieloznaczności wyrazu (Buttler 1968: 263). Kluczem do rozszyfrowania istoty kawału jest więc analiza jego językowego mechanizmu / językowych mechanizmów, czynników, które doprowadzają do komicznych kolizji sensów.

Przedstawione założenia badawcze rozważane będą na przykładzie współczesnego humoru oraz językowego obrazu świata niemieckiej grupy etnicznej. Obejmują one różne aspekty komunikacyjne osadzone w perspektywie społecznej: zarówno pragmatykę komunikacji międzykulturowej, kreatywność w komunikacji wewnątrzkulturowej, jak i humor w kulturze i komunikacji niemieckiej.

Ponieważ w ramach niniejszego opracowania nie sposób przeanalizować całego spektrum tematycznego właściwego humorystyce społeczności niemieckiej, zamierzenie badawcze zawężone zostanie do krótkiego omówienia istoty kawału w badaniach nad humorem oraz podjęcia próby kategoryzacji niemieckich kawałów (z konieczności ograniczeń poparte w każdej kategorii przykładowym kawałem niemieckim i jego tłumaczeniem na język polski ${ }^{1}$ ), jak również wyszczególnienie występujących w niemieckich kawałach mechanizmów językowych. W dalszej kolejności uwaga koncentruje się na krótkiej kognitywnolingwistycznej analizie niemieckiego kawału. Materiałem badawczym służącym przeprowadzeniu wyżej wspomnianej próby kategoryzacji i krótkiej analizy niemieckich kawałów jest korpus utworzony z ponad 400 niemieckich kawałów zaczerpniętych przede wszystkim $\mathrm{z}$ wybranych zbiorów internetowych takich jak: https://karpatenblatt.sk, https://ndr.de, https://www.spick.ch, http://witze.net. Korpus ten został utworzony z myślą o

\footnotetext{
${ }^{1}$ Wszystkie thumaczenia cytatów i kawałów niemieckich na język polski zamieszczone w niniejszym artykule są thumaczeniami autorskimi.
} 
kolejnych pracach nad niemieckimi kawałami. Wykorzystane w ramach niniejszego artykułu niemieckie kawały mają charakter przykładowy.

Jednostki językowe i ich znaczenie są zwykle badane w językoznawstwie kognitywnym w ścisłym związku z poznawczymi zdolnościami człowieka. W celu wyjaśnienia tego związku między semantyką a procesami poznawczymi, zwracam w tym badaniu szczególną uwagę na przypadki, gdy język „nie działa” z jednego lub więcej powodów. Do takich przypadków niefunkcjonowania $\mathrm{w}$ języku należą nieporozumienia. Typowym przypadkiem nieporozumienia językowego jest z pewnością gatunek 'kawał', w którym lawiruje się znaczeniami różnych jednostek językowych. Ritchie (2002: 54) stwierdza, że nieporozumienie jest podstawą żartu, mówiąc, że ,żart pojawia się w tekście, który wiąże się z niezrozumieniem spójności dyskursu lub ma zmienioną puentę, gdy wynikająca $\mathrm{z}$ tego interpretacja jest absurdalna lub tabu."2

Badania nad specyfiką niemieckich kawałów zmuszają do refleksji na temat natury świata i przywodzą na myśl różnorodne koncepcje opisujące wpływ języka na ludzkie myślenie czy postrzeganie, i prowadzą tym samym często do rozważań nad życiem społecznym czy też nad różnicami w obszarze mentalności różnych grup etnicznych. Nabierają one szczególnego wymiaru w kontekście swoistości narodowo-kulturowo-językowej, której aura mentalna określa sposób widzenia i poznawania świata (por. Gajda 2007: 18).

\section{Kawal w badaniach nad humorem}

Metodologia badań nad humorem jest bardzo rozbudowana, ponieważ humor stanowi bardzo rozległy obszar badawczy, w którym coraz częstsze są podejścia interdyscyplinarne, wyróżniające coraz to nowe aspekty oraz ich wzajemne korelacje współtworzące zjawisko komizmu. Bierze się to stąd, że ,zakres zjawisk, które mogłyby pretendować do miana komicznych, jest właściwie nieograniczony, »komiczność« nie jest bowiem stałą, immanentną cechą przedmiotów, ale realizuje się w pewnym doraźnym układzie sytuacyjnym i bywa wypadkową działania różnorodnych czynników” (Buttler 1968: 8). W ramach niniejszego opracowania opis dotychczasowych badań nad humorem zawężony zostanie do kategorii kawału przede wszystkim w polskiej i niemieckiej literaturze przedmiotu. Kawał traktowany jest przez wielu badaczy jako najbardziej reprezentatywna forma komizmu, a ponadto stanowić

\footnotetext{
2 ,In a text which constitutes a discourse-coherence misunderstanding or has punchline revision, if the resulting interpretation is Absurd or Taboo, the text constitutes a joke.“ (Ritchie 2002: 54)
} 
będzie przedmiot prowadzonej $\mathrm{w}$ dalszej części próby zaprezentowania różnych perspektyw badawczych i analizy językowej.

W badaniach naukowych kawał postrzegany jest jako ulotny komizm oraz pewna dyspozycja do „szybkiego chwytania i zestawiania podobieństw i różnic $\mathrm{w}$ rzeczach i wyobrażeniach" (Bogołębska 2000: 325), a cechami odróżniającymi go od innych form komizmu są: jego intelektualizm, neutralność uczuciowa, sprawność myślowa jego autora, ale też i odbiorcy, oraz specyficzny mechanizm wywoływania efektu komicznego (Buttler 1968: 33). Buttler (1968: 30-31) - celem terminologicznego ujednolicenia - proponuje, by kawał / dowcip definiować jako „wszelkie środki językowe zdolne przekazać »komiczną intencję« twórcy” lub jako „wszelkie formy świadomej twórczości językowej o charakterze żartobliwym” albo jako ściśle określoną strukturę „o stałej kompozycji, charakteryzującej się krótkością i zaskakującą pointą".

W badaniach nad istotą i strukturą kawałów wyróżnić można co najmniej kilka podejść, z których na uwagę zasługuje próba opisu, analizy i interpretacji struktury kawału za pomocą tzw. modelu izotopijno-dysjunkcyjnego, a więc przy użyciu konektorów i dysjunktorów. Umożliwiają one specyficzny sposób narracji właściwy kawałom. I tak, konektor pojawia się zwykle w kawałach językowych w fazie tzw. zawiązania akcji, a jako element o podwójnym znaczeniu umożliwia ,przejście między dwoma sensami [...] dowcipu” (Brzozowska 2000: 28). Po nim następuje dysjunktor w fazie rozwiązania, który sygnalizuje niemożność zrozumienia dowcipu w aktualnym trybie, a zatem konieczność przejścia na boczny tor rozumowania i reinterpretację konektora, oraz ukierunkowuje odbiorcę na odbiór znaczenia humorystycznego (ibid.). Aby zrozumieć dowcip, trzeba więc znaleźć w nim pewne informacje - te podane wprost, ale przede wszystkim i te ukryte, ponieważ sama (powierzchniowa) treść komunikatu (w kawale) często stanowi tylko niewielką część treści faktycznie w nim zawartych, które mniej lub bardziej współgrają z własnym wyobrażeniem o opisywanym fragmencie rzeczywistości. Konieczne jest także założenie oraz dostrzeżenie koherencji w na pierwszy rzut oka niespójnym tekście oraz wyodrębnienie izotopii, czyli takiego znaczenia, które można pogodzić z innymi elementami tekstu. Innymi słowy, chodzi o umiejętność zastosowania tzw. reguł kombinatorycznych, umożliwiających powiązanie ze sobą wszystkich możliwych skryptów oraz utworzenie tzw. sieci semantycznej i asocjacji konotacyjnych (Brzozowska 2000: 27-31). Dostrzeżenie zabawności kawału oraz poziom rozbawienia jego odbiorcy zależne są również od wielu innych czynników, takich jak: stopień niespójności zakończenia (im większe zaskoczenie pointą, tym większa intensywność doznań odbiorcy), liczba rozwiązanych bądź nierozwiązanych niespójności, stopień skomplikowania problemu i 
czasu potrzebnego do jego rozwiązania (kawał zbyt łatwy lub zbyt trudny do rozwiązania nie prowadzi do satysfakcji odbiorcy) oraz stopień ważności treści kawału dla odbiorcy (Chłopicki 1995: 32).

Humor jest pojęciem wielowarstwowym, obejmującym liczne gatunki, ale ich dokładne zróżnicowanie i opis funkcji w językoznawstwie z punktu widzenia Kotthoff (1998) są traktowane raczej bezładnie w porównaniu z tekstami nieżartującymi. Tak więc kategoria humoru nadal stanowi bardzo rozległy i niedokładnie zbadany dział w językoznawstwie (por. Kotthoff 1998: 11-12), który obejmuje na przykład satyrę, anegdotę, grę słów, aforyzm, kawał i inne formy (por. Köhler 2002: 259-260).

Wspólny dla wszystkich gatunków humorystycznych jest ich zamierzony efekt śmieszności. Według Raskina (1985) jest to nie tylko zjawisko fizjologiczne, ale także psychologiczne, które uwalnia nadmiar energii (psychicznej lub emocjonalnej), która nagromadziła się na przykład podczas słuchania humorystycznej wypowiedzi. Jednak śmiech może być również używany jako mechanizm obronny organizmu, na przykład jako metoda na radzenie sobie z odczuciem osobistego dyskomfortu, takiego jak wstyd lub gniew. Ponadto rozróżnia Raskin (1985) między śmiechem wywołanym z czystej radości i śmiechem z czegoś, co jest postrzegane jako zabawne. Na przykład w przypadku małych dzieci nie są one jeszcze wystarczająco biegłe w języku, aby móc śmiać się z treści humorystycznej wypowiedzi, ponieważ jej nie rozumieją. Jest to porównywalne z kawałem opowiedzianym komuś w zupełnie obcym języku: rodzaj zaprezentowania tego kawału może być zabawny, ale treść nie wywołuje śmiechu (por. Raskin 1985: 19-20).

Schubert (2014) rozumie humor jako "specyficzną dla danej kultury strategię komunikacyjną do osiągnięcia określonych celów"3 i jako "ogólną ludzką dyspozycję"4 (Schubert 2014: 17), która jest związana z językowym i pragmatycznym zakresem kompetencji danej osoby. Tak też można wytłumaczyć, dlaczego na przykład dzieci mają trudności ze zrozumieniem i prawidłową interpretacją humorystycznych środków stylistycznych takich jak ironia: ponieważ brakuje im niezbędnych strategii komunikacyjnych, których będą w stanie nauczyć się dopiero w późniejszym okresie życia.

Ponadto Schubert (2014) rozróżnia dwa aspekty istotne dla badań nad humorem: z jednej strony jest to jakościowa właściwość tekstów, obrazów i przedmiotów, które mają wywoływać uczucie radości / przyjemności; z drugiej strony humor reprezentuje cechę poznawczą

\footnotetext{
3 „kulturspezifische Kommunikationsstrategie zur Erlangung bestimmter Ziele“ (Schubert 2014: 17)

4 ,allgemeine menschliche Disposition“ (Schubert 2014: 17)
} 
charakteru, dzięki której osoby są w stanie śmiać się ze zjawisk humorystycznych (por. Schubert 2014: 17-18). Podobnie wygląda sytuacja z różnymi poziomami znaczeniowymi kawału, który według Schuberta (2014) stanowi konkretną manifestację humoru, i jako gatunek tekstu posiada także specyficzne cechy pod względem treści i struktury, w przeciwieństwie do nadrzędnej koncepcji humoru (por. Schubert 2014: 18).

Zgodnie z dzisiejszym rozumieniem kawał definiuje się jako krótką historyjkę, której kulminacją jest puenta i której głównym zadaniem jest wywołanie śmiechu (por. Röhrich 1977: 4-5).

\section{Kategoryzacja niemieckich kawałów i użytych w nich mechanizmów językowych}

Różnorodność dowcipów skłania do prób ich klasyfikacji. Nie jest to zamierzenie proste, ponieważ wiele proponowanych klasyfikacji wykazuje pewne nieścisłości lub też opiera się bądź na pokrywających się ze sobą kryteriach, bądź na kryteriach wzajemnie się wykluczających. Najbardziej ogólnym podziałem spotykanym w literaturze przedmiotu jest podział na kawały niewinne (abstrakcyjne) i satyryczne (tendencyjne, które dalej dzielą się na: agresywne, cyniczne i obsceniczne) oraz słowne (językowe) i rzeczowe (referencyjne, sytuacyjne) (Brzozowska 2000: 53; Buttler 1968: 38; Chłopicki 1995: 18).

Chłopicki (1995: 48-56) podaje również inną próbę klasyfikacji kawałów, wyróżniając 10 kategorii prowadzących do wywołania efektów komicznych. Są to: nowość i dziwność, deformacje ciała, deformacje moralne i wady, naruszenia porządku i reguł, niewielkie nieszczęścia, odniesienia do nieprzyzwoitości, udawanie, niespójności, brak wiedzy lub gra słów i dowcip.

Stosowane techniki to przede wszystkim: dwu- lub wieloznaczność, paradoksy stylistyczne, homonimia, gra słów, aliteracja, zniekształcenia stałych związków wyrazowych, modyfikacja formy fleksyjnej lub słowotwórczej wyrazu, ale także powtórzenia, różne nagromadzenia i wyliczenia oraz dysharmonia stylistyczna, a więc wplatanie $\mathrm{w}$ tekst słów o innej przynależności stylowej (regionalizmy, dialektyzmy, archaizmy, makaronizmy i inne) (Buttler 1968: 52-53).

W dalszej części niniejszego opracowania zostanie przedstawiona kategoryzacja kawału w oparciu o wprowadzone przez Kušnieriková (2013) trzynaście kategorii charakteryzujących bliżej gatunek tekstu 'kawał' z wykorzystaniem przykładów niemieckich kawałów i uwzględniając niemiecką specyfikę kulturową. Najpierw zostaną przedstawione uniwersalne 
kategorie, takie jak typ kawału w zależności od tematu, typ kawału w zależności od prezentowanej formy oraz ramy interpretacyjne i skrypty, które pojawiają się w niemieckich kawałach. Ponadto omówione zostanie słowo kluczowe / fraza kluczowa, na którym / na której oparty jest kawał, a następnie wyszczególnione specyficzne właściwości tekstu i procesy poznawcze za pomocą analizy dyskursu poznawczego. Ostatnie kategorie opisują, na czym polega czysto językowe nieporozumienie w kawale i które elementy kawału związane $\mathrm{z}$ językiem są specyficzne kulturowo.

\subsection{Typ kawału w zależności od tematu}

Przez typ kawału w zależności od tematu rozumiem zwykłą kategoryzację żartów, jak to zwykle realizuje się na stronach internetowych lub w różnych publikacjach. Przykłady typów kawału to kawały o lekarzu, Jasiu, blondynkach, o hrabii i Johnie, kawały szkolne, kawały o zwierzętach i wiele innych. Kategoria ta została uwzględniona w analizie ze względów praktycznych, głównie ze względu na łatwą identyfikację żartów, a także ze względu na częste połączenie z kategorią 'ramy interpretacyjne i skrypty'.

Przykład: kawał 1 (www.witze.net):

Der Schüler kommt zu spät zum Unterricht. Auf dem Weg in seine Klasse läuft er dem Schuldirektor über den Weg. „Eine Viertelstunde zu spät!” meint der Schuldirektor streng. ,Macht nichts! Ich auch!” erwidert der Schüler.

Spóźniony uczeń spotyka na korytarzu dyrektora. Dyrektor mówi surowo „Aż kwadrans spóźnienia!”, a uczeń na to „Nic nie szkodzi! Ja też!”

Typ kawału w zależności od tematu: kawał szkolny.

\subsection{Typ kawału w zależności od prezentowanej formy}

Prezentowaną formę postrzegam tutaj jako formę wypowiedzi, którą wybrał autor kawału. Większość żartów, które się pojawiają, ma formę dialogu, ale są też kawały narracyjne lub pseudo-dialogowe, np. w formie zagadki. Taka klasyfikacja kawałów ma na celu wskazanie, na jakim poziomie odbywają się procesy związane z kawałem: Albo autor kawału operuje tylko procesami kognitywnymi w mózgu odbiorcy (kawały narracyjne) albo do słowa dochodzą również procesy kognitywne uczestników żartu (kawały dialogowe i pseudo-dialogowe).

Przykład: kawał 2 (www.witze.net): 
„Franz, kennst du Beethovens Neunte?” - „Nein. Ich habe gar nicht gewusst, dass er so oft verheiratet war!"

„Franek, czy znasz Dziewiątą Beethovena?” - „Nie. Nawet nie wiedziałem, że był tyle razy żonaty!"

Typ kawału w zależności od prezentowanej formy: kawał dialogowy.

\subsection{Ramy interpretacyjne i skrypty}

Grishakova (2009: 190) twierdzi, że ramy interpretacyjne i skrypty sytuacji z dwuznacznością są kontenerem stereotypowej wiedzy, który obsługuje spontaniczne, zautomatyzowane działanie w dobrze znanych kontekstach opartych na regułach. Jest ono często postrzegane w kawałach. Teoria ram interpretacyjnych znajduje odzwierciedlenie w funkcjonowaniu języka. W większości przypadków można zaobserwować ramy w jednostkach, które wykraczają poza zdanie, czyli w kontekście, akcie mowy lub w dyskursie. W tym sensie ramy można również zidentyfikować w kawałach. Przemieszczenie ram (tzw. frameshifting) jest jednym $\mathrm{z}$ podstawowych elementów kawału. Chodzi tutaj o semantyczną i pragmatyczną reanalizę, w której elementy istniejącej wypowiedzi reprezentującej określoną wiadomość, są wstawiane do nowej ramy interpretacyjnej, która istnieje w długoterminowej pamięci odbiorców. Kawały są celowo tak tworzone, że sugerują jedną ramę interpretacyjną, chociaż ich elementy znajdują się w innej ramie.

Skrypty sytuacji z dwuznacznością są bardzo mocno związane z daną kulturą, czyli mogą być typowe dla konkretnego narodu, grupy etnicznej, grupy społecznej itp. Ten mechanizm jest wykorzystywany w wielu kawałach. Bardzo dobrze znane są np. kawały, które stosują ramy kultury szkockiej, blondynki, policjanta itp., w których neutralne skrypty i specyficzne skrypty nakładają się na siebie. W strukturze narracji kawału muszą istnieć dwa aktywowane skrypty lub reprezentacje wydarzeń na podstawie ram interpretacyjnych. Sytuacja przedstawiona w kawale musi być przynajmniej częściowo związana z każdym z dwóch aktywowanych skryptów, a kawał jest zabawny, ponieważ te skrypty są ze sobą sprzeczne.

Przykład: kawał 3 (www.ndr.de):

Ein ostfriesischer Lehrer wartet mit seinen Drittklässlern auf dem Bahnsteig. Einen Zug nach dem anderen lässt er passieren, ohne mit seiner Klasse einzusteigen. Schließlich platzt ihm der Kragen: „Den nächsten nehmen wir, Kinder. Auch wenn wieder nur 1. und 2. Klasse draufsteht!” 
Nauczyciel ze Wschodniej Fryzji czeka ze swoimi trzecioklasistami na peronie. Przepuszcza po kolei jeden pociąg za drugim, nie wsiadając do żadnego. W końcu nie wytrzymuje: „Dzieci, do następnego wsiadamy. Nawet jeśli znowu będzie tylko napis 1 i 2 klasa!"

Rama: Niemieckie kawały ilustrujące zachowanie mieszkańców Wschodniej Fryzji przedstawiają ich jako osoby głupie i są porównywalne z polskimi kawałami o mieszkańcach Wąchocka.

\subsection{Stowo kluczowe}

Przez słowo kluczowe mam na myśli jedno słowo w kawale, bez którego dany kawał nie może funkcjonować. Istnieją również kawały, w których istnieje kilka słów kluczowych, a nawet całe wyrażenie, które jest „niezrozumiane”.

Przykład: kawał 4 (www.witze.net):

„Zu welcher Familie gehören Delfine?““ will der Lehrer wissen. - „Weiß ich nicht”, meint Lisa, ,in unserer Straße hat keiner welche.”

„Do jakiej rodziny należą delfiny?” pyta nauczyciel. - „Nie wiem”, mówi Lisa, „Na naszej ulicy do żadnej."

Słowo kluczowe: rodzina.

\subsection{Akty mowy}

W analizie kawałów bardzo przydatne jest mówienie o aktach mowy (Searle 1979), ponieważ bardzo logiczne jest postrzeganie kawałów w taki sposób, aby ich słowa nie tylko opisywały fakty, ale także to, jakie działania są wykonywane. Akty mowy przebiegają na poziomie osoba mówiąca - odbiorca, ale także na poziomie między uczestnikami danego kawału. Semantyka kawału może być również postrzegana przez akty mowy na kilku poziomach, co jest związane $\mathrm{z}$ perspektywami różnych mówców i uczestników komunikacji w kawale. W szerszym znaczeniu tego słowa żart może być rozumiany jako akt mowy, zwłaszcza gdy myśli się o takim kawale, który z powodzeniem osiągnął swój komiczny efekt. Dotyczy to np. sytuacji, gdy zabawna historia powstaje z powodu nieporozumienia językowego.

Przykłąd: kawał 5 (www.witze.net):

Der Zauberer holt einen kleinen Jungen auf die Bühne: „Und du wirst bestätigen können, dass wir uns noch nie gesehen haben!“ - „Ja, Papa!” 
Magik zaprasza małego chłopca na scenę: „I możesz potwierdzić, że nigdy się nie widzieliśmy!” - „Tak, tato!”

Akt mowy: Stwierdzenie 'I możesz potwierdzić, że nigdy się nie widzieliśmy!' jest lokucyjnym aktem magika, który wykonuje illokucyjny akt rozkazu. Akt perlokucyjny magika jest potwierdzeniem nieznajomości między chłopcem a magikiem, ale tego efekt widać w perlokucyjnym akcie zdrady, który chłopiec wykonuje poprzez wyrażenie potwierdzenia oświadczeniem ‘Tak, tato!'.

\subsection{Spójność}

Kohezja i koherencja to dwa podstawowe mechanizmy spójności w tekście. Kawał jest semantycznie złożoną jednostką dyskursu. Tę złożoność kawału można zobaczyć z jednej strony w spójności semantycznej (koherencji), której koncepcje (presupozycje, ramy interpretacyjne, skrypty itp.) mają swoje zastosowanie w niniejszym artykule w kilku miejscach, $\mathrm{z}$ drugiej strony jest osiągana poprzez spójność na poziomie gramatycznym (kohezję), syntaktyczne połączenie kawału. Ponieważ jednak kawał dotyczy nieporozumienia językowego, poddawane analizie są w kawałach przede wszystkim te fragmenty, w których znalazły zastosowanie mechanizmy kohezji, doprowadzając do pewnego napięcia między tymi mechanizmami wśród uczestników żartu.

Badane środki spójności to pro-formy, deixis, substytucje, złącza, czasy i elipsy.

Przykład: kawał 6 (www.witze.net):

Vater Meier stellt sich in einer neuen Firma vor. „Haben Sie Kinder?” fragt der Personalchef. - „Ja, zwei!” - „Welches Fahrzeug benutzen Sie?” - „Ein Dreirad und ein Roller".

Ojciec Meier przedstawia się w nowej firmie. „Dzieci?” pyta szef działu kadr. - „Tak, dwoje!” - „Pojazd?”- „Rower trójkołowy i hulajnoga”.

Spójność: W tym kawale chodzi o spójność stworzoną przez ojca, ale która nie była zamierzona przez szefa działu kadr. Ojciec słyszy w języku niemieckim słowo 'sie' i rozumie je jako zaimek osobowy liczby mnogiej 'one' (dzieci) zamiast zaimka formy grzecznościowej 'Sie’ w znaczeniu 'Pan'. W przeciwieństwie do tego, co jest oczekiwane, następuje odpowiedź, która wywołuje komiczny efekt. 


\subsection{Konstrukcje semantycznie puste}

Chociaż w materiale badawczym nie było wiele kawałów z konstrukcjami semantycznie pustymi, to należy rozpatrywać tę kategorię oddzielnie. Semantycznie puste konstrukcje to takie, gdy słowo pojawia się w dyskursie bez żadnego znaczenia jako część zdania. Na przykład są one wprowadzane do konwersacji, aby wypełnić przerwy myślowe lub są zautomatyzowanym nawykiem mowy. W kawałach takie konstrukcje są ważne, gdy jeden z uczestników żartu przypisuje im pewne znaczenie. Jak widać na przykładzie, w kawałach może się zdarzyć również, że nieleksykalny dźwięk nabierze znaczenia.

Przykład: kawał 7 (www.spick.ch):

Sagt Fritz zu Paul: „Schau mal, mein Hund lügt!” Fritz: „Belo, wie macht eine Katze?” - „Wau, wau!”

Mówi Franek do Pawła: „Patrz, mój pies kłamie!” Franek: „Belo, jak robi kot?” „Hau hau!”

Semantycznie pusta konstrukcja: 'Wau, wau' w tym kawale przedstawia semantycznie pustą konstrukcję, ponieważ nie jest to wykrzyknik, tylko odgłos zwierzęcy. Żart polega na tym, że tej konstrukcji zostało przypisane znaczenie, a tym samym też wartość (prawda - nieprawda).

\subsection{Procesy poznawcze}

W świecie nauki istnieje wiele różnych sposobów podejścia do tego, czym dokładnie są procesy poznawcze, co należy do tej sfery i gdzie leży granica między poszczególnymi procesami. W tej kategorii wszystkie procesy, które mogą być postrzegane przez odbiorcę kawału lub przez uczestników kawału w kategoriach myślenia i poznania, należy opisać możliwie precyzyjnie.

Przykład: kawał 8 (www.spick.ch):

Die Mutter sagt zu ihrem Sohn: „Es heißt nicht 'Maul', sondern 'Mund“”. Da geht der Junge in den Garten und sagt zum Vater: „Du Papi, ich habe einen Film über Mundwurf gesehen."

Ze względu na nieprzetłumaczalność tego niemieckiego kawału na język polski podane zostaje tłumaczenie będące odpowiednikiem funkcjonującym w języku polskim:

Matka mówi do syna: „Nie mówi się ‘żre’, tylko ‘je'.” Potem chłopiec idzie do ogrodu i mówi do ojca: „Tato, wiesz co? Widziałem film o jadaczu białym.”

Procesy poznawcze w niemieckim kawale: 
a. Uczenie się - chłopiec dowiaduje się, że należy mówić 'usta' (niem. Mund), a nie 'gęba' (niem. Maul). Przechowuje to w swojej pamięci.

b. Rozpoznanie - rozpoznaje słowo 'Maul' (poln. 'gęba') w słowie 'Maulwurf' (poln. 'kret').

c. Przetwarzanie - przetwarza polecenie matki, że zamiast słowa 'gęba' należy używać słowa 'usta'.

d. Rozwiązanie problemu - rozwiązuje problem poprzez stworzenie nowego (nieistniejącego) słowa.

Procesy poznawcze w polskim kawale:

a. Uczenie się - chłopiec dowiaduje się, że należy mówić 'je', a nie 'żre'. Przechowuje to w swojej pamięci.

b. Rozpoznanie - rozpoznaje słowo 'żre' w słowie 'żarłacz'.

c. Przetwarzanie - przetwarza polecenie matki, że zamiast słowa ‘żre’ należy używać słowa 'je'.

d. Rozwiązanie problemu - rozwiązuje problem poprzez stworzenie nowego (nieistniejącego) słowa.

\subsection{Inferencja}

Inferencja to proces myślowy, w którym na podstawie zdań już uznanych za prawdziwe dochodzi się do uznania nowego twierdzenia. Inferencja jest więc procesem wnioskowania, powstałym w różnorodny sposób w trakcie komunikacji. Wiele kawałów jest wynikiem błędnego wnioskowania przez uczestnika żartu, lub też specjalnie przedstawia inferencje w taki sposób, żeby u odbiorcy nasunął się błędny wniosek.

Beispiel: kawał 9 (www.karpattenblatt.sk):

„Gnädiger Herr, Ihr Kules hat gerade eine Gans erdrosselt!” - „Wer ist denn Kules?” - „Na, Ihr Hund!” - „Aber er heißt Herkules!” - „Na freilich! Da werde ich dem Biest auch noch 'Herr' sagen müssen!'

„Łaskawy Panie, Pański Kules właśnie udusił gęś!” - „Kim jest Kules?” - „Ależ to Pański pies!” - „Przecież mój pies wabi się Herkules!” - „Jeszcze tego brakowało, żebym mówiąc o tej bestii musiał używać zwrotu 'Pan'!'

Inferencja: fałszywy wniosek pierwszego uczestnika żartu, który zinterpretował słowo 'Herkules' jako niemieckie sformułowanie 'Herr Kules', czyli po polsku 'Pan Kules'. 


\subsection{Presupozycje}

Kawały działają bardzo często z tzw. presupozycjami, czyli pozycjami przypuszczeń, które oparte są na warunkach wstępnych dotyczących wiedzy innych.

Przykład: kawał 10 (www.karpattenblatt.sk):

Fragt der Ober: „Ihr Glas ist leer. Möchten Sie noch eins?“ Darauf der Gast: „Nein, was soll ich mit zwei leeren Gläsern?"

Kelner pyta: „Pańska szklanka jest pusta. Czy chce Pan jeszcze jedną?” Na to gość: „Nie, po co mi dwie puste?”

Presupozycja: Kelner zakłada, ża gość zrozumie jego pytanie jako ofertę przyniesienia następnego napoju. Jednak jego przypuszczenie się nie potwierdza. Zamiast tego gość syntaktycznie łączy obydwa zdania wypowiedziane przez kelnera i wykorzystuje presupozycje o braku tej wiedzy u kelnera, wywołując tym samym komiczny efekt.

\subsection{Konotacja}

Konotacje oznaczają tutaj znaczenia drugorzędne. Kawały mogą zawierać konotacje wyrazów, zdań i tekstu. Bardzo często te konotacje są związane z elementami specyficznymi dla danej kultury. W kawałach konotacja jest zwykle narzędziem, które wzmacnia efekt komizmu.

Przykład: kawał 11 (www.hahaha.de):

Ein Mann spielt Schach mit seinem Hund. Ein zweiter Mann kommt dazu und sagt: „Sie haben aber einen klugen Hund.” Darauf der erste Mann: „Wieso, er verliert doch immer!"

Pewien mężczyzna gra ze swoim psem w szachy. Podchodzi do nich inny mężczyzna i mówi: „Ale ma pan ma pan mądrego psa.” Na to pierwszy: „No nie wiem, on zawsze przegrywa!"

Konotacja: Kawał jest konotacją. W powyższym przykładzie konotacją mądrości jest umiejętna gra w szachy jako przejaw wysoko rozwiniętych zdolności intelektualnych.

\subsection{Czysto językowe nieporozumienie}

Komiczny efekt kawałów polega w większości przypadków na językowym nieporozumieniu. Jego przyczyna leży w kompetencji językowej odbiorcy kawału. To nieporozumienie znajduje się w semantycznym ujęciu kawału i jest reprezentowane przez różne jednostki językowe, procesy poznawcze, itp. 
Przykład: kawał 12 (www.witze.net):

„Mein Name ist Kurz.” - „Meiner auch, ich heiße Lang.”

Ze względu na nieprzetłumaczalność na język polski tego niemieckiego kawału, którego kluczowymi słowami są wyrazy jednosylabowe ('Kurz', 'Lang'), niemające w języku polskim jednosylabowych odpowiedników, podane zostaje thumaczenie wolne, będące odpowiednikiem funkcjonującym w języku polskim:

„Jestem Spokojny” - „Ja też, jak mnie nikt nie drażni.”

Czysto językowym nieporozumieniem w niemieckim kawale jest błędna interpretacja funkcji części zdania słowa 'Kurz', które wydaje się homonimiczne w niemieckiej wymowie i może oznaczać w powyższym zdaniu zarówno podmiot (nazwisko 'Kurz') jak i orzecznik przymiotnikowy (niem. 'kurz' - pol. 'krótkie').

Czysto językowym nieporozumieniem w polskim kawale jest błędna interpretacja funkcji części zdania słowa ‘Spokojny’, które wydaje się homonimiczne w polskiej wymowie i może oznaczać w powyższym zdaniu zarówno podmiot (nazwisko 'Spokojny') jak i orzecznik przymiotnikowy ('spokojny').

\subsection{Specyfika kulturowa}

Wiele kawałów jest głęboko zakorzenionych w kulturze. To, z czego się śmiejemy, jest silnie związane ze znanym nam repertuarem kulturowym, pamięcią zbiorową i naszym wizerunkiem społeczeństwa. Specyfiką kulturową jest m.in. również odmienne poczucie humoru w różnych kulturach. Dlatego kawał może szybko utracić aspekt śmieszności i stać się obraźliwy i krzywdzący, jeśli opowiadający kawał mają inne pochodzenie kulturowe niż słuchający kawału. Ponieważ ludzkość żyje w zglobalizowanym świecie, różne kultury humoru zderzają się dziś znacznie szybciej niż kilka dziesiątek lat temu. Humor i wesołe usposobienie szybko może stać się naruszeniem, niepoprawnością polityczną, ponieważ w różnych kulturach istnieje nieidentyczny poziom tolerancji tabu.

Specyfika kulturowa obejmuje nie tylko szeroko zakrojoną kulturę krajów niemieckojęzycznych, w których dane kawały powstały, ale także mniejsze subkultury. Różnorodne elementy obcych kultur są wtedy brane pod uwagę, ponieważ mogą one wywołać konotacje lub zwiększyć efekt komiczny, które są wielce pożądane w kawałach.

Przykład: kawał 13 (www.witze.net):

„Nein, Frau Blaschke, die Intelligenz hat unser Sohn von meinem Mann. Ich habe meine noch..." 
„Nie, pani Blaschke, inteligencję odziedziczył nasz syn po moim mężu. Ja nadal jestem w posiadaniu mojej..."

Specyfika kulturowa: 'Frau Blaschke'. Słownik austriacki „Das Österreichische Volkswörterbuch” (www.volkswoerterbuch.at) podaje wyrażenie „das kannst der Frau Blaschke erzählen” (pol. „to możesz powiedzieć pani Blaschke”) w znaczeniu 'Nie wierzę ci ani trochę'. Tak więc wybór nazwy 'Blaschke' nie jest przypadkowy. Pani Blaschke jest w Austrii w powszechnej świadomości kimś, kto jest łatwowierny, wierzy w niesamowite historie. W powyższym kawale użycie nazwy 'Blaschke' podkreśla absurdalność tego kawału. Kawały o pani Blaschke w Austrii są porównywalne z kawałami o Masztalskim na Śląsku.

\section{Analiza niemieckiego kawału}

W dalszej części niniejszego opracowania zostanie przeprowadzona analiza niemieckiego kawału według wyżej wymienionych kategorii.

Przykład: kawał 14 (www.witze.net):

Der Chefkoch lässt die neue Kellnerin zu sich kommen. „Sagen Sie mal, wieso haben Sie denn Speinat auf die Speisekarte geschrieben?” „Sie haben doch selber gesagt,” wehrt sie sich, „ich soll Spinat mit Ei schreiben...”

Powyższy kawał nie jest przetłumaczalny dosłownie na język polski:

Szef kuchni wzywa kelnerkę. „Niech mi pani powie, czemu umieściła pani w menu szpeinak?” „Sam pan powiedział, żebym napisała szpinak przez ei...” [Kelner miał na myśli szpinak z jajkiem.]

Analizowany kawał należy do grupy kawałów w restauracji, biorąc pod uwagę typ kawału w zależności od tematu. Istnieją również pojęcia bardziej szczegółowe jak: kawały o kelnerach, kelnerkach, kucharzach, kucharkach lub szefach kuchni. Źródłem tego kawału jest nowoczesny zbiór kawałów opublikowany w Internecie na wyżej wymienionej stronie, ale kawał ten można również znaleźć na wielu innych portalach, przy czym zmiany w wariantach tego kawału zachodzą zwykle w występujących tam osobach (kelner, kelnerka, uczeń, uczennica, kucharz, kucharka, kucharz praktykant, kucharka praktykantka, szef kuchni, szefowa kuchni itp.).

Jeśli chodzi o typ tego kawału w zależności od prezentowanej formy wypowiedzi, to jest ten kawał dialogiem z dwoma uczestnikami, ale możliwe byłoby również opowiedzenie tego kawału używając formy narracyjnej, a nie dialogowej, gdyż kawał ten posiada prosty do opowiedzenia wątek. 
Teraz przejdźmy do analizy dialogu. Pierwszy uczestnik dialogu - szef kuchni - wydał pewne polecenie. Powiedział mianowicie kelnerce - drugiemu uczestnikowi dialogu -, aby napisała „szpinak z jajkiem”. Stworzył przy tym presupozycję, wychodząc z założenia, że kelnerka wie, iż „szpinak z jajkiem” jest daniem oferowanym danego dnia w tej restauracji. Jednak przypuszczenie szefa kuchni nie zostało spełnione, gdyż kelnerka wysunęła błędny wniosek, myśląc, że szef kuchni zlecił jej napisanie słowa „szpinak” wykorzystując w słowie dyftong „-ei”. Dochodzi do rozbieżności znaczeń między formą pisaną i formą ustną. Niemieckie słowo „Ei” (pol. ,jajko”) i dyftong ,-ei-” pisze się inaczej, ale brzmią tak samo. Występuje tutaj zjawisko homonimii, które stanowi pierwsze podłoże językowego nieporozumienia w tym kawale.

Oprócz homonimii występuje w tym kawale również wieloznaczność (polisemia), która także tworzy podłoże językowego nieporozumienia. Wieloznaczność znajduje się w zdaniu podrzędnym ,ich soll Spinat mit Ei schreiben.” Zakłócenie / nieporozumienie wywołane jest tutaj różnymi funkcjami składniowymi poszczególnych słów. Szef kuchni używa wyrażenia „Spinat mit Ei” jako dopełnienia z przydawką (pol. ,,szpinak z jajkiem”), podczas gdy kelnerka odbiera to sformułowanie jako zwrócenie uwagi na pisownię dania wyrażone okolicznikiem sposobu „Spinat (geschrieben) mit -ei-” (pol. „szpinak (napisane) przez -ei”). Znaczącą rolę odgrywa tutaj łącznik ,mit”. W obu przypadkach jego spójność ma bowiem inną semantykę. W „Spinat mit -ei“ łącznik „mit” występuje w roli partytywa, w relacji przynależności. W wyrażeniu „Spinat mit Ei” dotyczy on natomiast połączenia z atrybutem fakultatywnym, który jest przeciwieństwem niemieckiego przyimka „ohne” (pol. „,bez”).

Trzecim podłożem nieporozumienia językowego $\mathrm{w}$ analizowanym kawale jest nieznajomość przez szefa kuchni procesów językowych kelnerki. Polecenie szefa kuchni kelnerka rozumie jako zalecenie innej pisowni, które realizuje tworząc sztuczny paronim „Speinat” (poprzez wymianę litery „i,” na dwuznak „ei”). Owe słowo jest słowem kluczowym tego kawału. Należy zaznaczyć, że analizowany kawał jest zakotwiczony w niemieckiej leksyce i nie działa w języku polskim. Ten kawał jest nieprzetłumaczalny / nieprzekładalny na język polski. Kluczowe wyrazy występujące w tym kawale mają bowiem swoistą strukturę znaczeniową i składniową, różniącą się od siebie znacząco $w$ języku niemieckim i polskim.

W analizowanym kawale efekt komizmu wywołany zostaje również przez aspekt fonetyczny, a dokładniej mówiąc przez onomatopeiczne wzmocnienie efektu komizmu poprzez korelację „ei” nowo powstałego paronimu „Speinat” z innymi podobnie brzmiącymi sformułowaniami występującymi w tekście niemieckiego kawału, a mianowicie ze słowami „Speisekarte” (pol. menu) i wspomnianymi już „mit Ei” und „mit -ei”. 
Fonetycznie można też uzasadnić błędne wnioskowanie (inferencję) kelnerki. Wyznacznikiem specyfiki kulturowej i regionalnej jest między innymi inna wymowa słów w różnych regionach Niemiec. W języku dolnoniemieckim dyftong „ei” wymawia się jak ,iil” (np. w bajce braci Grimm „Von den Fischer und siine Fru” (dt. „Von dem Fischer und seiner Frau” pol. „O rybaku i złotej rybce”). Zakładając więc, że owa kelnerka jest członkiem grupy językowej mówiącej językiem dolnoniemieckim, mogłaby wywnioskować, że szef kuchni znając jej braki językowe w języku standardowym niemieckim zwraca jej uwagę na pisownię, chcąc tym samym uniknąć błędnej ortografii. Nieznajomość takiej funkcji fonetycznej jest kolejnym podłożem językowych nieporozumień.

Rozpatrując fabułę analizowanego kawału można zauważyć następujące akty mowy: 1. Sednem kawału jest akt lokucyjny, w tym przypadku pisemny akt kelnerki. 2. Była to reakcja kelnerki na illokucyjny akt rozkazu szefa kuchni. 3. Napięcie występuje między aktem perlokucyjnym szefa kuchni i 4. efektem perlokucyjnym wywołanym przez kelnerkę.

\section{Wnioski}

Przedmiotem niniejszego artykułu było ustalenie i próba opisu mechanizmów językowych mających swoje zastosowanie w tworzeniu nieporozumień językowych w krótkich formach humorystycznych, jakimi są kawały, jak również zaprezentowanie różnych perspektyw badawczych i ich zastosowanie do analizy kawałów. Ten w konieczności pobieżny i schematyczny przegląd mechanizmów językowych na przykładzie niemieckich kawałów miał na celu ukazanie ich kognitywno-semantycznych struktur. Przedstawiona egzemplifikacja to tylko mały wycinek bardzo szerokiego spektrum, które należałoby pogłębić w kolejnych pracach nad niemieckimi kawałami.

W przypadku grupy etnicznej jaką reprezentuje społeczność niemiecka, szczególnie widoczna jest w kawałach specyfika kulturowa zorientowana wokół pracy, szkoły oraz więzi regionalnych. Częstym elementem generującym efekty komiczne jest dwuznaczność powodująca konieczność uruchomienia u odbiorcy kawału najpierw interpretacji pierwotnego znaczenia, a następnie przebudowy dokonanej interpretacji semantycznej, a więc jej reinterpretacji wprowadzającej znaczenie alternatywne.

Reasumując, można stwierdzić, że poprzez kawał należy rozumieć niezależnie funkcjonującą jednostkę, przy czym to funkcjonowanie jest osiągane przez specjalnie użyte niefunkcjonowanie (nieporozumienie). $Z$ językowego punktu widzenia jest to paradoks, ja nazwałabym go komicznym paradoksem. 


\section{Bibliografia}

Bogołębska, Barbara (2000) „Między humorem, dowcipem i komizmem (śmiesznością), czyli o zmaganiach terminologicznych autorów poetyk XIX i początku XX w. [W:] Stanisław Gajda, Dorota Brzozowska (red.) Świat humoru. Opole: Uniwersytet Opolski; 321-329. Brzozowska, Dorota (2000) O dowcipach polskich i angielskich. Aspekty językowo-kulturowe. Opole: Uniwersytet Opolski.

Buttler, Danuta (1968) Polski dowcip językowy. Warszawa: Polskie Wydawnictwo Naukowe. Chłopicki, Władysław (1995) O humorze poważnie. Kraków: Wydawnictwo Oddziału PAN.

Gajda, Stanisław (2007) „Współczesny dyskurs komiczny”. [W:] Jan Mazur (red.) Humor i karnawalizacja we współczesnej komunikacji językowej. Lublin: Wydawnictwo Uniwersytetu Marii Curie-Skłodowskiej; 11-19.

Grishakova, Marina (2009) „Beyond the Frame: Cognitive Science, Common Sense and Fiction“. Narrative, 17 (2); 188-199.

Hartmann, Roger (2020) „Witze”. Spick - magazyn internetowy dla dzieci i młodzieży w Szwajcarii. [pobrane z https://www.spick.ch/dein-spick/witze/. Data ostatniego dostępu: 21.11.2020].

Köhler, Peter (2002) „Witz“. [W:] Sonja Hilzinger (red.) Kleine literarische Formen in Einzeldarstellungen. Ditzingen: Reclam; 259-272.

Kothoff, Helga (1998) Spaß verstehen: Zur Pragmatik von konversationellem Humor. Tübingen: Niemeyer.

Kušnieriková, Jarmila (2013) „Sprachliche und kognitive Mechanismen in Witzen”. Motus in verbo: časopis mladej vedeckej generácie. T. 2; 45-55.

Litschko, Katrin (2020), ,Witz der Woche”. Karpatenblatt - Portal internetowy Stowarzyszenia Podkarpackich Niemców: Magazyn Niemców na Słowacji. [pobrane z https://karpatenblatt.sk. Data ostatniego dostępu: 18.11.2020].

Raskin, Victor (1985) Semantic Mechanisms of Humor. Dordrecht: D. Reidel.

Rasmussen, Niels (2020) „Hänschen Kiechererbse und sein neuer Witz”. NDR.de - Das Beste am Norden - Radio - Fernsehen. [pobrane z https://www.ndr.de. Data ostatniego dostępu: 01.12.2020]. 
Ritchie, Graeme (2002) „The structure of forced reinterpretation jokes”. [W:] Oliviero Stock, Carlo Strapparava, Anthony Nijholt (red.) April Fool's Day Workshop on Computational Humor (TWLT 20). Enschede: University of Twente; 47-56.

Röhrich, Lutz (1977) Der Witz: Figuren, Formen, Funktionen. Stuttgart: Metzler.

Roschk, Steffen (2020) „Schule Witze”. Witze.net-najlepszy zbiór kawałów w sieci. [pobrane $\mathrm{z}$ http://witze.net. Data ostatniego dostępu: 02.12.2020].

Russwurm, Roland (2020) „Wörter des Tages: Frau Blaschke”. Volkswörterbuch - Internetowy Stownik Austriacki. [pobrane z https://www.volkswoerterbuch.at. Data ostatniego dostępu: 20.11.2020].

Schubert, Christoph (2014) Kommunikation und Humor: Multidisziplinäre Perspektiven. Berlin: LIT.

Searle, John R. (1979) Expression and Meaning: Studies in the Theory of Speech Acts. Cambridge: Cambridge University Press. 